\title{
Agronomic performance of green cane fertilized with ammonium sulfate in a coastal tableland soil
}

Ana Paula Pessim Oliveira ${ }^{1 \star}$, Bruno José Rodrigues Alves², Lúcia Helena Cunha dos Anjos ${ }^{1}$ Eduardo Lima $^{1}$, Everaldo Zonta ${ }^{1}$, Willian Pereira ${ }^{1}$, Paula Fernanda Chaves Soares ${ }^{1}$

1. Universidade Federal Rural do Rio de Janeiro - Instituto de Agronomia - Departamento de Solos - Seropédica (RJ), Brazil.

2. Embrapa - Centro Nacional de Pesquisa de Agrobiologia - Seropédica (RJ), Brazil.

ABSTRACT: The recent approach of eliminating the usage of fire for sugarcane harvesting resulted in managing the crop on a trashblanketed soil, to which a proper recommendation of $\mathrm{N}$ fertilization is lacking, a problem that remains in the coastal tablelands of the Espírito Santo State, Brazil. This study aimed at evaluating the effect of increasing $\mathrm{N}$ rates on stalk and sugar yields and the $\mathrm{N}$ use efficiency by the crop. The experimental area planted with sugarcane, at the first ratoon, is located in Linhares, Espírito Santo State. The treatments consisted of $\mathrm{N}$ rates varying from 80 to $160 \mathrm{~kg} \mathrm{~N} \cdot \mathrm{ha}^{-1}$ as ammonium sulphate, and a control without $\mathrm{N}$, in a completely randomized blocks experimental design. Stalk yield increased with the $\mathrm{N}$ rate, and fitting the results to a quadratic function suggests no response to fertilizer rates above $130 \mathrm{~kg} \mathrm{~N} \cdot \mathrm{ha}^{-1}$. The highest margin of agricultural contribution was obtained at the rate of $100 \mathrm{~kg} \mathrm{~N} \cdot \mathrm{ha}^{-1}$. The $\mathrm{N}$ use efficiency decreased from almost 49 to $38 \%$, when the $\mathrm{N}$ rate increased from 100 to $160 \mathrm{~kg} \mathrm{~N} \cdot \mathrm{ha}^{-1}$. There was no effect of increasing N rates on the sugar concentration, although the sugar yield response was positive and strongly influenced by the stalk production. Results showed the importance of reassessing the adequate $\mathrm{N}$ rate for maximizing yield in green cane production systems.

Key words: Saccharum spp., sugarcane harvesting systems, nitrogen requirements. 


\section{INTRODUCTION}

In 2014, the area of sugarcane production in Brazil was close to 10 million hectares (IBGE 2016), and about 65\% of this area was harvested without previous burning (INPE 2014). The suppression of fire before harvesting characterizes what is known as green cane, in which 12 to $20 \mathrm{Mg} \cdot \mathrm{ha}^{-1}$ of straw (dry-mass basis) are produced every year to form a trash-blanket covering the soil for most of the re-growing cycle (Robertson and Thorburn 2007a).

Nitrogen is usually a limiting nutrient to crop yield in the weathered tropical soils, and positive yield responses to $\mathrm{N}$ fertilization are observed for sugarcane in Brazil (Dourado Neto et al. 2010; Fortes et al. 2013), although less frequently to plant cane (first cycle) owing to higher contribution from $\mathrm{N}$ in soil and residue due to $\mathrm{N}$ mineralization, as well as the biological nitrogen fixation (Balasubramanian et al. 2004; Urquiaga et al. 2012; Otto et al. 2016). A review on sugarcane pointed out the relatively low $\mathrm{N}$ use efficiency (NUE) by the crop, which averages $26 \%$ from a range of 7 to $40 \%$ of the $\mathrm{N}$ fertilizer applied. Including the fraction of $\mathrm{N}$ fertilizer remaining in the soil, less than $60 \%$ of the applied $\mathrm{N}$ is accounted for in the soil-plant system after harvesting (Otto et al. 2016), which indicates high $\mathrm{N}$ losses.

Urea is the most common $\mathrm{N}$ fertilizer source for crops in Brazil, and it is widely used in sugarcane areas in top-dressing fertilization. However, its application on the trash blanketed may induce high $\mathrm{N}$ losses by $\mathrm{NH}_{3}$ volatilization (Costa et al. 2003; Cantarella et al. 2007), and cane yield may be negatively affected (Costa et al. 2003). On the other hand, the application of $70 \mathrm{~kg} \mathrm{~N} \cdot \mathrm{ha}^{-1}$ as ammonium sulfate to a second ratton of sugarcane resulted in greater stalk yield $\left(76 \mathrm{Mg}^{-h a^{-1}}\right)$ than when urea was the $\mathrm{N}$ fertilizer source $\left(57 \mathrm{Mg} \cdot \mathrm{ha}^{-1}\right)$, since the latter resulted in ammonia volatilization losses of $46 \%$ of the $\mathrm{N}$ applied (Vitti et al. 2007). The $\mathrm{N}$ losses associated to urea may explain the lowest levels of NUE quantified for sugarcane crop, mainly when the crop is managed without burning for harvest (Vieira-Megda et al. 2015).

The use of $\mathrm{N}$ sources less susceptible to loss by ammonia volatilization when fertilizers are applied to the soil surface, such as ammonium sulfate and ammonium nitrate, is nowadays a common practice. However, there is not much information on suitable $\mathrm{N}$ rates for high cane yield when the fertilizer is broadcast applied onto the cane trashblanket; and the fertilizer $\mathrm{N}$ recommendatioN.has been the same as that when the crop was burnt for harvesting. The presence of trash at the time the fertilizer is applied may bring about physical and biological interactions that might limit the efficiency of $\mathrm{N}$ fertilizer assimilation by plants (Gava et al. 2005). There is evidence that the soil organic $\mathrm{N}$ pool, and consequently the mineral $\mathrm{N}$ availability, could increase in the long-term until a new equilibrium is reached (Robertson and Thorburn 2007b), but, to guarantee high yields greater fertilizer $\mathrm{N}$ rates might be required, at least in the short-term. On the other hand, the application of $\mathrm{N}$ in excess of plant demand can decrease the sucrose concentration in the fresh stalks (Wiedenfeld 1995), negatively affecting its commercial value.

A reduction in Pol (sucrose content in cane juice) and in total recoverable sugar was verified by Ambrosano et al. (2005) when the crop was subjected to a high dose of $\mathrm{N}$ from green manure combined with ammonium sulfate fertilization. However, such situation is not always observed, as the increase in stalk yield as a function of $\mathrm{N}$ fertilization generally offsets the Pol reduction bringing about gains in sugar yield (Franco et al. 2010; Fortes et al. 2013). Also, the excess of $\mathrm{N}$ may have potential deleterious off-set impacts to the environment (Martinelli and Filoso 2008), which makes essential to investigate the $\mathrm{N}$ rate for improving the efficiency of this nutrient taken up by the plants.

Sugarcane has been cropped in areas of tableland relief (gently rolling relief in a continuous plateau) of the Brazilian coastal region for centuries (Boddey et al. 2003). However, apart from economic importance of the activity for many states in this region, not much has been done to improve the $\mathrm{N}$ fertilizer management for the crop, especially when managed unburned with a trash blanket left on soil after the mechanical harvest. This is critical for the Espírito Santo State, Brazil, whose sugarcane areas are settled in the northern region, such as in the Municipalities of Linhares, Conceição da Barra, and Montanha, with average yields of about $70 \mathrm{Mg} \cdot \mathrm{ha}^{-1}$ (IBGE 2016) under a recommended N fertilization rate of $80 \mathrm{~kg} \cdot \mathrm{ha}^{-1}$, the same as that when fire was used for harvesting.

The hypothesis behind this study is that stalk and sugar yield of green sugarcane cropping areas in northern Espírito Santo State will show a positive response to $\mathrm{N}$ fertilization rates over $80 \mathrm{~kg} \mathrm{~N} \cdot \mathrm{ha}^{-1}$. Besides measuring stalks and sugar yield under increasing $\mathrm{N}$ rates as ammonium sulfate, the objective of this study included measurements of NUE by the crop in the tableland region. 


\section{MATERIAL AND METHODS}

The study was carried out in Linhares, Espírito Santo State, southeastern Brazil (lat $19^{\circ} 18^{\prime} \mathrm{S}$ and long $40^{\circ} 19^{\prime} \mathrm{W}$ ), located in a cane production farm of LASA Sugar and Ethanol Plant. The region's physiography is known as lowlands of the Doce River and it has a tableland relief. The soil was classified as Xhantic Dystrudults (Soil Survey Staff 2014).

The area of the experiment ( $2.24 \mathrm{ha}$ ) has been under commercial cultivation of green cane since 2007, and, before that, it was under pasture coverage with low-intensity management. The experimental plots were set up in the year of 2009, when the crop was renewed and the cultivar RB 918639, which has an average maturity and good budding of the ratoon under the trash, was planted. Some soil chemical and physical characteristics in the experimental area are displayed in Table 1 . This study was performed during the first ratoon, from November 2010 to September 2011. The climatic conditions during the study are presented in Figure 1.

After the mechanical harvesting, the plots were delimited, and 5 treatments, composed of increasing $\mathrm{N}$ rates $(80 ; 100$; 120 and $160 \mathrm{~kg} \mathrm{~N} \cdot \mathrm{ha}^{-1}$ ) as ammonium sulfate and the control (without $\mathrm{N}$ ), were arranged in completely randomized blocks with 5 replicates. The fertilizer management practices followed those regularly applied by the sugarcane plantation. The area of each plot was of $70 \mathrm{~m}^{2}$ with 5 plant rows of $10 \mathrm{~m}$ length spaced by $1.4 \mathrm{~m}$. For the respective plots, each $\mathrm{N}$ rate was manually applied on the trash blanket at a $0.2 \mathrm{~m}$ distance from the sugarcane row. Phosphorus, $\mathrm{K}$, and fritted micronutrients were also applied at the rates of $100 \mathrm{~kg} \mathrm{P} \cdot \mathrm{ha}^{-1}$ as single superphosphate, $100 \mathrm{~kg} \mathrm{~K} \cdot \mathrm{ha}^{-1}$ as
$\mathrm{KCl}$, and $40 \mathrm{~kg} \cdot \mathrm{ha}^{-1}$ of FTE BR12 (9\% Zn; $1.8 \% \mathrm{~B} ; 0.8 \% \mathrm{Cu}$; $2 \% \mathrm{Mn} ; 3.5 \% \mathrm{Fe}$ and $0.1 \% \mathrm{Mo}$ ), respectively, but without liming application. Exclusively for the $\mathrm{N}$ rates of 100 and $160 \mathrm{~kg} \mathrm{~N} \cdot \mathrm{ha}^{-1}$, microplots of $2.8 \mathrm{~m}$ width by $3 \mathrm{~m}$ length were delimited in the main plots to receive the ammonium sulfate enriched at $10 \mathrm{~atm} \%{ }^{15} \mathrm{~N}$ instead of the unlabelled fertilizer.

For the main plots, 2 sugarcane rows from an area of $4.8 \mathrm{~m}^{2}$ were sampled to evaluate the crop performance. The harvested plants were separated into stalks, dead leaves, and top leaves (remaining green leaves at the top of the plant), each part being subsampled and dried in an air forced oven at $65{ }^{\circ} \mathrm{C}$ for dry mass determination. Stalks were also weighed fresh for the yield estimation. The same procedure was repeated with the sampled material from the central area of each microplot where the ${ }^{15} \mathrm{~N}$ fertilizer was added.

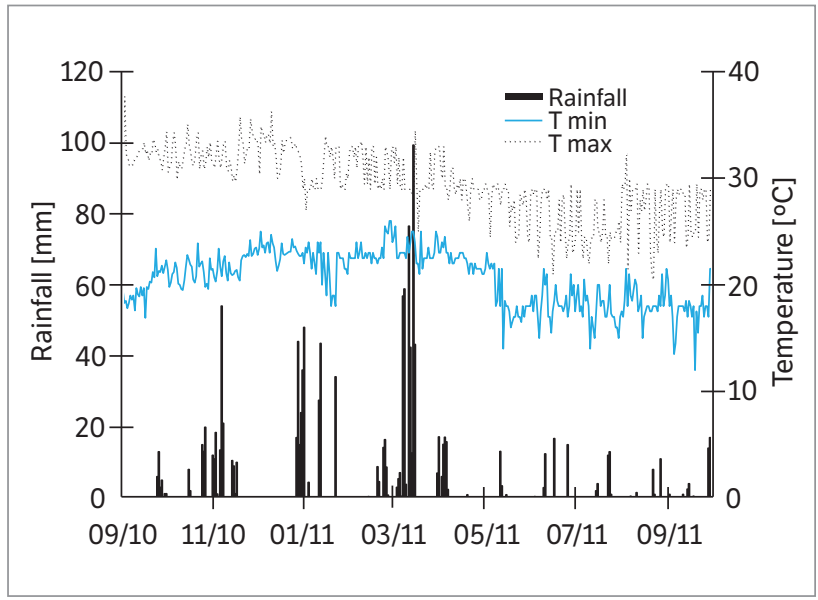

Figure 1. Rainfall as well as maximum and minimum temperatures (Tmax and Tmin, respectively) registered during the sugarcane study cycle.

Table 1. Soil chemical and physical characteristics of samples taken from sugarcane experimental area at LASA Sugar and Ethanol Plant, Linhares Municipality, Espírito Santo, Brazil.

\begin{tabular}{|c|c|c|c|c|c|c|c|c|c|c|c|}
\hline \multirow{2}{*}{$\begin{array}{l}\text { Soil } \\
\text { depth } \\
\text { (cm) }\end{array}$} & \multirow[b]{2}{*}{$\mathbf{H}+\mathbf{A l}$} & \multicolumn{10}{|c|}{ Chemical analyses } \\
\hline & & $\underset{\left(\mathrm{cmol}_{\mathrm{c}} \cdot \mathrm{dm}^{-3}\right)}{\mathrm{Al}}$ & $\begin{array}{c}\mathrm{Ca} \\
\left(\mathbf{m g} \cdot \mathrm{dm}^{-3}\right)\end{array}$ & $\underset{\left(\mathbf{g} \cdot \mathbf{k g} \mathbf{g}^{-1}\right)}{\mathbf{M g}}$ & $\begin{array}{c}\text { BS } \\
\text { (water) }\end{array}$ & CEC & $\mathbf{K}^{+}$ & $\mathbf{P}^{(1)}$ & $O C^{(2)}$ & $\mathbf{N}$ & pH \\
\hline $0-20$ & 2.2 & 0.4 & 0.5 & 0.3 & 0.83 & 3.15 & 48 & 4.2 & 17.6 & 0.62 & 5.4 \\
\hline $20-40$ & 2.6 & 0.5 & 0.5 & 0.3 & 0.83 & 3.52 & 37 & 3.9 & 16.7 & 0.54 & 5.2 \\
\hline \multirow{3}{*}{$\begin{array}{l}\text { Soil } \\
\text { depth } \\
(\mathrm{cm})\end{array}$} & \multirow{3}{*}{$\begin{array}{l}\text { Soil bulk } \\
\text { density } \\
\left(\mathbf{k g} \cdot \mathbf{m}^{-3}\right)\end{array}$} & \multicolumn{10}{|c|}{ Physical analyses } \\
\hline & & Sand & Silt & & Cla & & \multirow{2}{*}{\multicolumn{5}{|c|}{ Soil texture class }} \\
\hline & & \multicolumn{5}{|c|}{$\mathbf{g} \cdot \mathbf{k g}^{-1}$} & & & & & \\
\hline $0-20$ & 1.570 & 860 & \multicolumn{2}{|l|}{50} & \multicolumn{2}{|c|}{90} & \multicolumn{5}{|c|}{ Loamy sand } \\
\hline $20-40$ & 1.550 & 830 & \multicolumn{2}{|l|}{70} & \multicolumn{2}{|c|}{100} & \multicolumn{5}{|c|}{ Loamy sand } \\
\hline $40-60$ & 1.410 & 800 & 70 & & 13 & & \multicolumn{5}{|c|}{ Sandy loam } \\
\hline
\end{tabular}

${ }^{(1)}$ Available P (Mehlich-1); ${ }^{(2)} \mathrm{C}$ - Walkey-Black. BS = Base saturation; CEC = Cation exchange capacity; OC = Organic carbon. 
Air temperature and rainfall were monitored during crop growth by a meteorological station located about $5 \mathrm{~km}$ from the experimental area.

\section{Cane yield and industrial quality}

Cane yield was estimated based on the weight of fresh stalks. Dry matter accumulation, Brix (mass percentage of soluble solids in the cane juice), Pol (mass percentage of apparent sucrose contained in the cane juice), juice purity (mass percentage of apparent sucrose in the soluble solids of the cane juice, estimated by the equation $\mathrm{Q} \%=100 \times \mathrm{Pol} / \mathrm{Brix}$ ), fibre content (estimated by the equation $\mathrm{F} \%=(0.08 \times$ bagasse fresh weight $)+0.876)$, reducing sugar (mass percentage of reducing sugars in the juice estimated as $\mathrm{RS} \%=3.641-(0.0343 \times \mathrm{Q}))$, total recoverable sugar (estimated by the equation TRS $=(9.5263 \times \mathrm{Pol})+$ $(9.05 \times \mathrm{RS} \times(\mathrm{F}-0,01 \times \mathrm{F}) \times(1.0313-0.00575 \times \mathrm{F}))$, as well as sugar and ethanol production were used as parameters for evaluating the technological quality of the juice for industrial purposes, whose definitions and calculations were adapted from Consecana (2006). These analyses were performed by taking 3 stalks at random from the total stalk sampled of each plot.

\section{Nutrient accumulation in sugarcane}

The oven-dried material was ground in a Wiley mill (40 - 80 mesh) for determination of nutrient content. Nitrogen was measured by the Kjeldahl technique (Bremner and Mulvaney 1982), and P, K, as well as Ca and Mg, by spectrophotometry, flame ionization, and atomic absorption spectrometry, respectively, after the nitroperchloric digestion (Silva 1999). Total nutrient accumulation by aerial tissues was quantified from plant dry matter accumulation and nutrient content. The fraction exported from the area was that one accumulated in stalks.

\section{Fertilizer $\mathrm{N}$ use efficiency}

Subsamples of the grounded material were powdered $(<200$ mesh) in a ball-mill (Arnold and Schepers 2004) for ${ }^{15} \mathrm{~N}$ enrichment analysis by isotope-ratio mass spectrometry, according to Dumas method as described in Ramos et al. (2001). To calculate the fertilizer NUE, the proportion of plant $\mathrm{N}$ derived from fertilizer (\%Ndff) was estimated as follows:

$$
\% \mathrm{Ndff}=\left(\%{ }^{15} \mathrm{~N}_{\mathrm{p}} / \%{ }^{15} \mathrm{~N}_{\mathrm{f}}\right) \times 100
$$

where: $\%{ }^{15} \mathrm{~N}_{\mathrm{p}}$ and $\%{ }^{15} \mathrm{~N}_{\mathrm{f}}$ are, respectively, the atom $\%$ of ${ }^{15} \mathrm{~N}$ in excess in the plant and in the fertilizer.

The total $\mathrm{N}$ accumulated by the plant $\left(\mathrm{N}_{\mathrm{p}}\right.$ in $\left.\mathrm{kg} \cdot \mathrm{ha}^{-1}\right)$ was multiplied by \%Ndff to obtain the amount of $\mathrm{N}$ derived from fertilizer, which was divided by the amount of fertilizer $\mathrm{N}$ applied $\left(\mathrm{N}_{\mathrm{f}}\right.$ in $\left.\mathrm{kg} \cdot \mathrm{ha}^{-1}\right)$ to estimate the NUE (\%), as follows:

$$
\operatorname{NUE}(\%)=\left(\% \text { Ndff } \times \mathrm{N}_{\mathrm{p}}\right) / \mathrm{N}_{\mathrm{f}}
$$

\section{Contribution margin}

The contribution margin is defined as the difference between market revenue and total variable cost as proposed by Fernandes (2011). In this study, the fertilizer cost is the variable cost, and the farm revenue represents the profit from selling the sugar produced with the fertilizer. The costs of cane cutting, loading, and transportation were also added to fertilizer cost, since these operations varied as a function of stalk yield. The profitability was calculated by deducing contribution margin of control treatment (no $\mathrm{N}$ fertilization) from the values obtained with different $\mathrm{N}$ fertilizer rates treatments.

\section{Statistics}

Analysis of variance was performed using the F-test $(p=0.05)$ after checking for normality of errors applying the Lilliefors test and the homogeneity of variance was verified by Cochran's and Bartlett's test. Given the quantitative nature of the primary variable (fertilizer $\mathrm{N}$ rate), significant contrasts were adjusted by regression analysis. The statistical packages SAEG v. 9.1 (UFV 2007) and GraphPad Prism 4 (GraphPad Software Inc., La Jolla, CA, USA) were used to run the analyses.

\section{RESULTS AND DISCUSSION}

Total rainfall during the experimental period was of $1,248 \mathrm{~mm}$ from which about $80 \%$ occurred during the first 6 months of plant growth. The average rainfall for the region oscillated between 1,000 to $1,250 \mathrm{~mm}$ according to reports of the sugar plant company where the experimental area is located. 


\section{Cane yield and industrial quality}

Cane yield varied from 73.8 to $105.1 \mathrm{Mg} \cdot \mathrm{ha}^{-1}$ in the $\mathrm{N}$ doses from 0 to $100 \mathrm{~kg} \mathrm{~N} \cdot \mathrm{ha}^{-1}$, but there was a decreasing yield gain as the $\mathrm{N}$ rate increased. Such trend was best fit $(\mathrm{p}<0.0011)$ to a quadratic model and brought about a theoretical maximum yield at an $\mathrm{N}$ rate of $130 \mathrm{~kg} \mathrm{~N} \cdot \mathrm{ha}^{-1}$ (Figure 2). The dry matter accumulation of top and dead leaves did not show a significant response to $\mathrm{N}$ fertilization despite of a quadratic tendency (Table 2). On average, top and dead leaves dry matter production were 5.4 and $7.1 \mathrm{Mg} \cdot \mathrm{ha}^{-1}$, respectively. Both plant parts remained on the soil as trash-blanket after plant harvest, and they represented between 27 and $35 \%$ of the whole

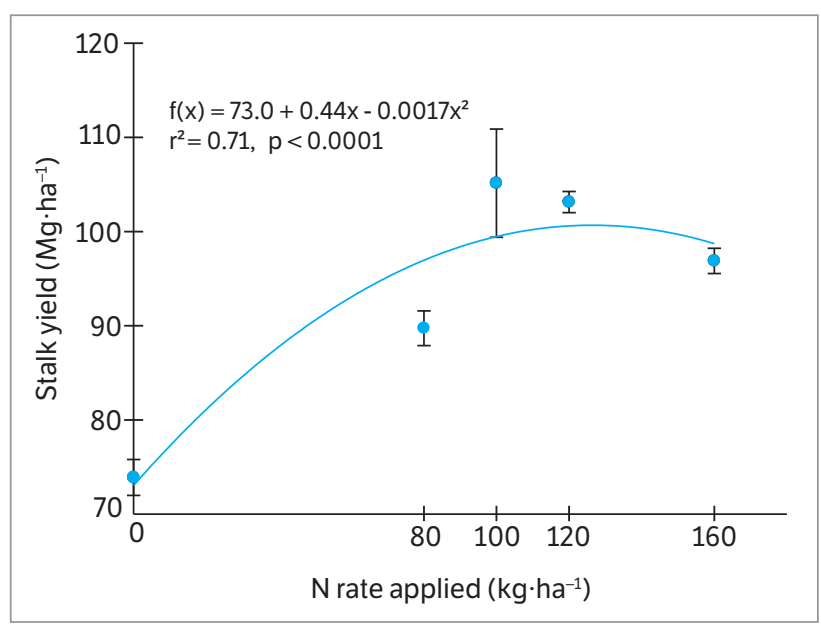

Figure 2. Stalk yield by the sugarcane cv RB918639 at the first ratoon crop in response to increasing fertilizer $\mathrm{N}$ rates as ammonium sulphate. Bars indicate standard error of the mean.

Table 2. Dry matter of straw, top leaves, and total straw left as trash blanket after harvesting of sugarcane cv RB 918639, plant cycle, with increasing $\mathrm{N}$ rates as ammonium sulphate, and significance of linear and quadratic regression based on dry mass and $\mathrm{N}$ rate

\begin{tabular}{|c|c|c|c|}
\hline \multirow{2}{*}{$\begin{array}{l}\text { Fertilizer } \mathbf{N} \text { rate } \\
\qquad\left(\mathbf{k g} \cdot \mathbf{h} \mathbf{a}^{-1}\right)\end{array}$} & Dead leaves & Top leaves & \multirow{2}{*}{ Total } \\
\hline & \multicolumn{2}{|c|}{$\left(M g \cdot h a^{-1}\right)$} & \\
\hline 0 & 7.2 & 5.5 & 12.6 \\
\hline 80 & 7.1 & 5.1 & 12.2 \\
\hline 100 & 8.1 & 5.6 & 13.7 \\
\hline 120 & 7.1 & 5.6 & 12.7 \\
\hline 160 & 6.1 & 5.1 & 11.2 \\
\hline LR & ns & ns & ns \\
\hline QR & ns & ns & ns \\
\hline CV (\%) & 14.2 & 12.1 & 10.4 \\
\hline
\end{tabular}

$\mathrm{LR}=\mathrm{Linear}$ regression; $\mathrm{ns}=$ Non-significant; $\mathrm{QR}=$ Quadratic regression; $\mathrm{CV}=$ Coefficient of variation. shoot dry mass, which was not influenced by the $\mathrm{N}$ fertilization rate too.

The industrial characteristics of the sugarcane juice were not much influenced by the $\mathrm{N}$ fertilization. Brix varied from 20 to $21^{\circ}$, fibre content from 10 to $12 \%$, purity was about $90 \%$, and reduced sugars, $0.6 \%$ (Table 3). The $\mathrm{N}$ fertilization only affected the apparent sucrose content in the sugarcane juice, which followed a quadratic response. The highest Pol of 19.3 was obtained for the $\mathrm{N}$ rate of $80 \mathrm{~kg} \mathrm{~N} \cdot \mathrm{ha}^{-1}$, decreasing to 17.3 with the highest $\mathrm{N}$ rate. Total recoverable sugar as well as sugar and ethanol yields also presented quadraticresponse trends with maximum value at $100 \mathrm{~kg} \mathrm{~N} \cdot \mathrm{ha}^{-1}$ (164 $\mathrm{kg} \cdot \mathrm{Mg}^{-1} ; 20 \mathrm{Mg} \cdot \mathrm{ha}^{-1}$ and $92 \mathrm{~L} \cdot \mathrm{Mg}^{-1}$, respectively).

\section{Nutrient extraction}

Even though stalk represented the highest proportion of shoot dry matter ( 70\%), the accumulation of nutrients other than $\mathrm{N}$ and Ca was roughly similar between stalk and dead + top leaves (Table 4). Calcium accumulated mostly in dead + top leaves, while $\mathrm{N}$ was predominant in the stalks. The accumulation of nutrients $(\mathrm{N}, \mathrm{P}, \mathrm{K}, \mathrm{Ca}$, and $\mathrm{Mg}$ ) in stalk and in dead + top leaves followed the trends observed for the dry mass accumulation in response to $\mathrm{N}$ fertilization. However, the quadratic behaviour was only significant for $\mathrm{N}$ and $\mathrm{K}$ in stalks. On average, the total of $\mathrm{P}, \mathrm{Ca}$, and $\mathrm{Mg}$ extracted iN.harvested stalks were equivalent to $7.0 ; 10.3$ and $13.7 \mathrm{~kg} \cdot \mathrm{ha}^{-1}$, respectively, while the remaining amounts as trash were, respectively, 5.7; 26.6 and $14.7 \mathrm{~kg} \cdot \mathrm{ha}^{-1}$.

Nitrogen and K were the nutrients accumulated in the greatest quantities in sugarcane shoots, with the former reaching $93.6 \mathrm{~kg} \cdot \mathrm{ha}^{-1}$ in the control treatment, but increasing to a maximum of $151.5 \mathrm{~kg} \cdot \mathrm{ha}^{-1}$ for the fertilization with $100 \mathrm{~kg} \mathrm{~N} \cdot \mathrm{ha}^{-1}$. For the maximum fertilization of $160 \mathrm{~kg} \mathrm{~N} \cdot \mathrm{ha}^{-1}, \mathrm{~N}$ accumulation in shoots decreased to $116.5 \mathrm{~kg} \mathrm{~N} \cdot \mathrm{ha}^{-1}$. Potassium accumulation in plant shoots was $134.2 \mathrm{~kg} \cdot \mathrm{ha}^{-1}$ in the control, with a peak of $181.4 \mathrm{~kg} \cdot \mathrm{ha}^{-1}$ at $100 \mathrm{~kg} \mathrm{~N} \cdot \mathrm{ha}^{-1}$ fertilization, decreasing to $152.8 \mathrm{~kg} \mathrm{~K} \cdot h \mathrm{~h}^{-1}$ at the maximum $\mathrm{N}$ fertilization rate.

The maximum amounts of $\mathrm{N}$ and $\mathrm{K}$ exported in stalks were in the order of $100 \mathrm{~kg} \cdot \mathrm{ha}^{-1}$ approximately (Table 4). On average, the remaining quantities in trash were equivalent to 44 and $77 \mathrm{~kg} \cdot \mathrm{ha}^{-1}$ of $\mathrm{N}$ and $\mathrm{K}$, respectively. Exported $\mathrm{P}$ by stalk harvest was less than $9 \mathrm{~kg} \cdot \mathrm{ha}^{-1}$, while exported Ca and $\mathrm{Mg}$ were about 10 and $15 \mathrm{~kg} \cdot \mathrm{ha}^{-1}$; in all cases, almost a tenth of the $\mathrm{N}$ and $\mathrm{K}$ were exported from the system. 
Table 3. Technological indices of cane juice evaluated as a function of $\mathrm{N}$ rate as ammonium sulphate applied to the sugarcane cv RB 918639 at the plant cycle.

\begin{tabular}{|c|c|c|c|c|c|c|c|c|}
\hline \multirow{2}{*}{$\begin{array}{l}\text { Fertilizer N rate } \\
\qquad\left(\mathbf{k g} \cdot \mathbf{h} \mathbf{a}^{-1}\right)\end{array}$} & ${ }^{\circ}$ Brix & Fibre & Pol $I^{(1)}$ & Purity & Reducing sugars & \multirow{2}{*}{$\begin{array}{l}\text { Total recoverable sugar } \\
\left(\mathbf{k g} \cdot \mathrm{Mg}^{-1}\right)\end{array}$} & \multirow{2}{*}{$\begin{array}{l}\text { Sugar yield } \\
\left(\mathbf{M g} \cdot \mathbf{h a}^{-1}\right)\end{array}$} & \multirow{2}{*}{$\begin{array}{l}\text { Ethanol } \\
\left(\mathrm{L} \cdot \mathrm{Mg}^{-1}\right)\end{array}$} \\
\hline & \multicolumn{5}{|c|}{ (\%) } & & & \\
\hline 0 & 20.3 & 11.6 & 18.5 & 90.8 & 0.49 & 153.1 & 13.6 & 86.1 \\
\hline 80 & 21.2 & 11.4 & 19.3 & 91.1 & 0.48 & 161.9 & 17.3 & 91.0 \\
\hline 100 & 21.1 & 10.7 & 19.0 & 90.4 & 0.63 & 164.2 & 20.0 & 92.3 \\
\hline 120 & 20.3 & 11.0 & 18.5 & 89.2 & 0.66 & 156.2 & 19.1 & 87.8 \\
\hline 160 & 20.1 & 10.8 & 17.3 & 88.5 & 0.58 & 147.0 & 16.8 & 82.6 \\
\hline LR & ns & ns & ns & ns & ns & ns & ns & ns \\
\hline QR & ns & ns & * & ns & ns & * & * & * \\
\hline CV (\%) & 3.2 & 2.2 & 3.6 & 3.7 & 8.1 & 2.3 & 4.7 & 2.3 \\
\hline
\end{tabular}

(1)Percentage of sucrose; *Significant at 1\% probability. LR = Linear regression; $n s=$ Non-significant; QR = Quadratic regression; CV = Coefficient of variation.

Table 4. Nutrient accumulated in stalks and straw + top leaves of the sugarcane cv RB918639, at the first ratoon crop, harvested without burning of straw and fertilized with increasing $\mathrm{N}$ rates as ammonium sulphate.

\begin{tabular}{|c|c|c|c|c|c|c|c|c|c|c|}
\hline \multirow{3}{*}{$\begin{array}{c}\text { N rate } \\
\left(\mathbf{k g}^{\left.-h^{-1}\right)}\right.\end{array}$} & \multicolumn{5}{|c|}{ Stalks } & \multicolumn{5}{|c|}{ Straw + top leaves } \\
\hline & $\mathbf{N}$ & $\mathbf{P}$ & $\mathbf{K}$ & $\mathbf{C a}$ & $\mathbf{M g}$ & $\mathbf{N}$ & $\mathbf{P}$ & $\mathbf{K}$ & $\mathrm{Ca}$ & Mg \\
\hline & \multicolumn{10}{|c|}{$\left(\mathbf{k g} \cdot h a^{-1}\right)$} \\
\hline 0 & 54.6 & 5.6 & 55.6 & 8.9 & 10.9 & 39.0 & 5.9 & 78.6 & 28.1 & 14.9 \\
\hline 80 & 76.3 & 6.5 & 80.9 & 8.7 & 13.3 & 42.5 & 5.4 & 73.6 & 25.9 & 14.8 \\
\hline 100 & 99.9 & 8.1 & 98.4 & 13.6 & 15.5 & 51.6 & 6.0 & 83.0 & 29.5 & 15.7 \\
\hline 120 & 100.8 & 7.5 & 94.2 & 11.1 & 15.9 & 47.0 & 5.7 & 78.1 & 25.6 & 14.2 \\
\hline 160 & 77.4 & 7.4 & 81.7 & 9.5 & 13.0 & 39.3 & 5.6 & 71.0 & 23.9 & 13.9 \\
\hline LR & ns & ns & ns & ns & ns & ns & ns & ns & ns & ns \\
\hline QR & ** & ns & ** & ns & ns & ns & ns & ns & ns & ns \\
\hline CV (\%) & 6.9 & 14.9 & 7.3 & 31.5 & 14.7 & 9.8 & 10.2 & 18.2 & 15.1 & 12.5 \\
\hline
\end{tabular}

${ }^{*}$ Significant at $5 \%$ probability. LR = Linear regression; $n s=$ Non-significant; $Q R=$ Quadratic regression; $C V=$ Coefficient of variation.

\section{Nitrogen use efficiency}

The accumulated $\mathrm{N}$ amounts in the aerial tissues of the sugarcane plants grown in the microplots, fertilized with 10 and $16 \mathrm{~g} \mathrm{~N} \cdot \mathrm{m}^{-2}$ as ${ }^{15} \mathrm{~N}$ enriched ammonium sulfate, were similar, close to $19.5 \mathrm{~g} \mathrm{~N} \cdot \mathrm{m}^{-2}$ (Table 5). Stalks accumulated $14 \mathrm{~g} \mathrm{~N} \cdot \mathrm{m}^{-2}$ or $72 \%$ of the $\mathrm{N}$ in aerial part of the plant. The atom $\%{ }^{15} \mathrm{~N}$ in excess in plant parts varied from $0.859( \pm 0.043)$ to $1.124( \pm 0.139)$ in stems, $0.615( \pm 0.074)$ to $0.847( \pm 0.127)$ in top leaves, and $0.967( \pm 0.078)$ to $1.149( \pm 0.089)$ in dry leaves, respectively, for the 10 and $16 \mathrm{~g} \mathrm{~N} \mathrm{~m}^{-2}$ fertilization.

There was a marked trend of decrease in the efficiency of the $\mathrm{N}$ fertilizer taken up by the plant when the $\mathrm{N}$ rate increased. The NUE was approximately 49 and $39 \%$ for the $\mathrm{N}$ rates of 10 and $16 \mathrm{~g} \mathrm{~N} \cdot \mathrm{m}^{-2}$, respectively. Most of the $\mathrm{N}$ accumulated by the plants derived from soil, which was equivalent to 74 and $67 \%$, respectively, for treatments receiving 10 and
$16 \mathrm{~g} \mathrm{~N} \cdot \mathrm{m}^{-2}$ (Table 5 ). Less than $15 \%$ of the $\mathrm{N}$ fertilizer was present in top and dead leaves, which composed the trash after harvesting.

The quadratic response found in this study indicates that a stalk production of $102 \mathrm{Mg} \cdot \mathrm{ha}^{-1}$ was the maximum attainable for the prevailing conditions, which corresponded to an $\mathrm{N}$ fertilization rate of $130 \mathrm{~kg} \mathrm{~N} \cdot \mathrm{ha}^{-1}$ (maximum of the curve) using ammonium sulfate (Figure 2). A quadratic response to $\mathrm{N}$ fertilization was also observed by Castro et al. (2014) using ammonium nitrate as $\mathrm{N}$ source for a sugarcane crop growing on a clayey soil, to which a maximum cane yield of $119 \mathrm{Mg} \cdot \mathrm{ha}^{-1}$ obtained with $144 \mathrm{~kg} \mathrm{~N} \cdot \mathrm{ha}^{-1}$ was reported. These results occurred independently of the harvesting system (green or burnt) or the use of subsoiling operation in the interrow space.

It is not plausible that cane yield response in this study is related to sulfur $(S)$ in the fertilizer, since there is 
Table 5. Total $\mathrm{N}$ accumulated, nitrogen in the plant derived from fertilizer, proportion of $\mathrm{N}$ fertilizer recuperated, and $\mathrm{N}$ derived from soil by different parts of sugarcane cv RB918639, at the first ratoon crop and under $2 \mathrm{~N}$ rates.

\begin{tabular}{|c|c|c|c|c|}
\hline \multirow{2}{*}{ N rate } & Stalk & $\begin{array}{l}\text { Top } \\
\text { leaves }\end{array}$ & $\begin{array}{l}\text { Dead } \\
\text { leaves }\end{array}$ & Shoots \\
\hline & \multicolumn{4}{|c|}{ Total N $\left(\mathbf{k g} \cdot \mathrm{ha}^{-1}\right)$} \\
\hline 100 & 135.24 & 39.73 & 21.51 & 196.48 \\
\hline 160 & 141.02 & 34.28 & 18.72 & 194.03 \\
\hline CV (\%) & 10 & 16 & 13 & 11 \\
\hline N rate & \multicolumn{4}{|c|}{ Ndff $\left(k g \cdot h a^{-1}\right)$} \\
\hline 100 & 35.1 & 7.4 & 6.3 & 48.9 \\
\hline 160 & 47.1 & 8.8 & 6.5 & 62.3 \\
\hline CV (\%) & 25 & 25 & 24 & 23 \\
\hline N rate & \multicolumn{4}{|c|}{$\mathbf{R} \%$} \\
\hline 100 & 35.13 & 7.44 & 6.31 & 48.88 \\
\hline 160 & 29.43 & 5.47 & 4.05 & 38.95 \\
\hline CV (\%) & 26 & 28 & 27 & 25 \\
\hline N rate & \multicolumn{4}{|c|}{ NFS (kg·ha-1 } \\
\hline 100 & 100.11 & 32.28 & 15.20 & $147.60 \mathrm{a}$ \\
\hline 160 & 93.94 & 25.53 & 12.24 & $131.70 \mathrm{~b}$ \\
\hline CV (\%) & 9 & 15 & 11 & 6 \\
\hline
\end{tabular}

The absence of letters in the column indicates that there were no differences between treatments at $5 \%$ by Tukey's test. CV $=$ Coefficient of variation; $\mathrm{Ndff}=$ Nitrogen in the plant derived from fertilizer; \% $\mathrm{R}=$ Proportion of $\mathrm{N}$ fertilizer recuperated; NFS = Nitrogen from soil.

regular fertilization of the crop with products containing $S$ (ammonium sulfate, single superfosfate, etc.) and lacking reports on $\mathrm{S}$ deficiency symptoms. Other studies, such as Prado and Pancelli (2008), Franco et al. (2010), and Fortes et al. (2013), using different types of $\mathrm{N}$ fertilizers, reported cane yield responses to $\mathrm{N}$ fertilization that fit to a quadratic function, but linear responses or the absence of response to $\mathrm{N}$ fertilization were also reported depending on locality and ratoon cycle.

There is little biological basis to select a model over another to describe the crop response to $\mathrm{N}$ fertilization (Mead and Pike 1975). Nonetheless, a common trend for cropping systems is the decreasing yield gain with increasing $\mathrm{N}$ rate, which is reasonably well described by the quadratic function.

The variability on the intensity of cane yield responses to $\mathrm{N}$ fertilization is probably related to nutritional limitation, water stress or physical impairment to root growth, as reckoned by Rosa et al. (2015). These authors observed linear yield responses to $\mathrm{N}$ fertilization in 2 experiments when sugarcane was at second ratoon on soils of moderate and high clay content, and no responses from 2 other experiments on clayey soils when cane was at the fourth ratoon. Damages to the crop by consecutive harvests and soil compaction were listed as possible reasons for the contrasting responses to $\mathrm{N}$ fertilization. However, it seems that limitations to plant response to $\mathrm{N}$ fertilization is not explained by a unique factor, as Prado and Pancelli (2008) obtained positive responses in stalk yield at the second ratoon but not at the first. Water availability is an important factor affecting cane yield in different levels depending on the period that soil water deficit occurs (Wiedenfeld 1995), which was also one of the factors pointed out by Prado and Pancelli (2008) to explain their results.

In this study, cane crop was in the first ratoon, and rainfall was within the normal range for the region, being although more frequent during the first half of the plant growth cycle (Figure 1), which possible favoured crop response to $\mathrm{N}$ fertilization. The relatively high soil organic matter content could be considered as a reducing factor in the $\mathrm{N}$ fertilizer response, since it leads to high supply of $\mathrm{N}$ through mineralization of organic matter reserves (Dourado Neto et al. 2010). However, the high proportion of undecomposed plant material in the soil organic matter identified by the C:N ratio of 28 to 30 (Table 1) could be acting more as a sink than a source of $\mathrm{N}$.

The immobilization of $\mathrm{N}$ fertilizer by the trash blanket of high $\mathrm{C} / \mathrm{N}$ ratio (Meier et al. 2006) requires higher fertilizer $\mathrm{N}$ rates to attain a similar stalk yield when the residues are burnt. Hence, the yield response to $\mathrm{N}$ fertilization might be greater than that observed in this study, even though the maximum stalk yield of $100 \mathrm{Mg} \cdot \mathrm{ha}^{-1}$ was very good for a ratoon crop, well above the region average of $70 \mathrm{Mg} \cdot \mathrm{ha}^{-1}$ (IBGE 2016). This supports the hypothesis that the recommended $\mathrm{N}$ rate of $80 \mathrm{~kg} \cdot \mathrm{ha}^{-1}$, considered optimum for the sugarcane cropping systems based on burning the cane for harvesting (UFRRJ 2013), is below the value required for the crop when it is greeN.harvested. Besides the field experiments, results of a simulation study (Oliveira et al. 2015) to evaluate impact of trash management on sugarcane production and $\mathrm{N}$ fertilizer requirements, in the same coastal tablelands environment, reinforce the upper $\mathrm{N}$ requirement of the green cane, mainly in the beginning of the adoption of this system.

Other factors such as the low soil cation exchange capacity (CEC) and soil acidity could have contributed to limit the plant response to $\mathrm{N}$ fertilization (Table 1). The low availability of $\mathrm{K}^{+}$in the soil $\left(<1.6 \mathrm{mmol}_{c} \cdot \mathrm{dm}^{-3}\right)$ combined to a ratio $\mathrm{K}^{+}\left(\mathrm{Ca}^{2+}+\mathrm{Mg}^{2+}\right)^{-0,5}$ below 0.2547 suggests a nutritional 
limitation for sugarcane (Reis Junior. 2001), even though the increase in $\mathrm{K}$ accumulation in plant material had increased with $\mathrm{N}$ fertilization. This trend was not observed for $\mathrm{P}, \mathrm{Ca}$, and $\mathrm{Mg}$ (Table 4).

The efficiency of $\mathrm{N}$ fertilizer uptake by sugarcane was approximately $49 \%$ when the equivalent to $100 \mathrm{~kg} \mathrm{~N} \cdot \mathrm{ha}^{-1}$ was applied (Table 5), and this value was well above the range of 5 to $30 \%$ reported for the crop in other regions (Meier et al. 2006; Trivelin et al. 1996; Franco et al. 2011; Otto et al. 2016). The lowest efficiencies of $\mathrm{N}$ acquisition by sugarcane can be a consequence of $\mathrm{N}$ source and rainfall, when there is no other apparent limitation for the plant growth. Cantarella et al. (2008) reported ammonia volatilization as high as $25 \%$ of the applied $\mathrm{N}$ at rates up to $100 \mathrm{~kg} \mathrm{~N} \cdot \mathrm{ha}^{-1}$ as urea, when the fertilizer was broadcasted on the trash-blanketed soil, but almost nothing when $\mathrm{N}$ source was ammonium sulfate. This would explain the relatively high fertilizer $\mathrm{N}$ acquisition efficiency by the plants found in this study. However, this efficiency dropped down to $39 \%$ when $\mathrm{N}$ rate increased to $160 \mathrm{~kg} \mathrm{~N} \cdot \mathrm{ha}^{-1}$, which is commonly explained by the decreasing yield effect that plants may show under high nutrient supply (Baligar et al. 2001). This usually happens due to genotypic and physiological constraints, the latter dependent on relationship among plant performance and the environment.

The $\mathrm{N}$ fertilizer has a key role for the earlier stages of ratoon cane growth, as more than $2 / 3$ of $\mathrm{N}$ in plant may be derived from fertilizer, but, as a consequence of soil $\mathrm{N}$ availability, the final NUE can be low (Franco et al. 2011; Dourado Neto et al. 2010). According to Brackin et al. (2015), the increase in mineral $\mathrm{N}$ availability after fertilization exceed in several orders of magnitude (200 to $3,000 \%)$ the $\mathrm{N}$ uptake by sugarcane roots. The $\mathrm{N}$ in excess is retained by charged soil particles, lost from the system or immobilized by soil microorganisms. The present study's soil has a low CEC, thus the relatively higher NUE reported would be mainly associated to the retention of fertilizer $\mathrm{N}$ by soil microbial biomass, which was favoured by the high C:N ratio of soil organic matter. The slower $\mathrm{N}$ turnover through microbial and organic pools would be more closely matching root $\mathrm{N}$ uptake (Brackin et al. 2015), increasing fertilizer $\mathrm{N}$ recuperation by the plant.

Notwithstanding, the $\mathrm{N}$ from fertilizer did not represent more than half of the total $\mathrm{N}$ accumulated by sugarcane plants (Table 5), indicating that other $\mathrm{N}$ sources were important to plant growth. The equivalent to 50 to $60 \mathrm{~kg} \mathrm{~N} \cdot \mathrm{ha}^{-1}$ returned to the soil as green and dead leaves that composed the trash left on the soil, which corresponded to less than $25 \%$ of the total $\mathrm{N}$ accumulated in the plants' aerial tissues. This is an indication that the existing residues contributed little to the crop $\mathrm{N}$ demand, since only part of the $\mathrm{N}$ in the straw is liberated during the following cane growing cycle (Fortes et al. 2012), which would contain only 10 to $12 \%$ of the $\mathrm{N}$ supplied from $\mathrm{N}$ fertilization (Table 5). This indicates that native soil $\mathrm{N}$ played an important role for sugarcane yield. In addition, the possibility of a contribution of biological nitrogen fixation (BNF) to the plants that may reach up to $40 \mathrm{~kg} \mathrm{~N} \cdot \mathrm{ha}^{-1} \cdot \mathrm{year}^{-1}$ (Urquiaga et al. 2012) cannot be neglected.

One of the concerns about the addition of $\mathrm{N}$ fertilizer to sugarcane is the reduction of sugar yield (Wiedenfeld 1995). According to Korndorfer and Martins (1992), $\mathrm{N}$ fertilization is usually associated with increased vegetative growth, which invariably determines plants with higher moisture content and lower sucrose content. In this study, there was only a trend on declining Brix values with increase in the $\mathrm{N}$ rate (Table 3 ). The total recoverable sugars, Pol, and sugar yield followed the same quadratic trend of the stalk production. Fibre content and juice purity were not affected by the increase in the $\mathrm{N}$ rates. Franco et al. (2010) observed small but significant decrease in Pol and total recoverable sugars, while Fortes et al. (2013) observed increased sugar yield linearly dependent on $\mathrm{N}$ fertilizer rate applied to a sugarcane ratoon crop. For the present study, increase in $\mathrm{N}$ rate also promoted $\mathrm{K}$ absorption by the plant, which is related to sugar translocation (Yamada et al. 2002), explaining the similar accumulation patterns; however, there is a potential limitation for $\mathrm{N}$ fertilization response due to limiting nutrient availability.

While small effects of $\mathrm{N}$ fertilization on sugar content are reported, a stronger positive effect on sugar yield is observed as it is calculated as a function of stalk yield, a variable generally dependent on $\mathrm{N}$ fertilization for ratoon cycles. This means that the negative effect on sugar content is largely offset by the positive effect of $\mathrm{N}$ fertilization on stalk production, which makes it more valuable the optimization of $\mathrm{N}$ fertilization for the sugarcane crop.

To illustrate the economical implications of the results, when taking into consideration the regional costs for harvesting and stalk transport (US\$ 4.00 per 
ton of stalks) and cost of fertilization (US\$ 1.31 per kg of $\mathrm{N}$ as ammonium sulfate), a total cost varying from US\$ 303.7 to US\$ 607.0 was obtained for the control (without N) for $160 \mathrm{~kg} \mathrm{~N} \cdot \mathrm{ha}^{-1}$ fertilizer rates. The gross income based on the sugar yield obtained from each $\mathrm{N}$ rate varied from $1,865.00$ to $2,350.33$, respectively, for control (zero N) and $160 \mathrm{~kg} \mathrm{~N} \cdot \mathrm{ha}^{-1}$. This value peaked at US $\$ 2,848.00$ for the $100 \mathrm{~kg} \mathrm{~N} \cdot \mathrm{ha}^{-1}$ treatment, assuming revenue of US\$ 0.125 per ton of sugar. The surplus was estimated by the difference between gross income and total cost. Finally, the net income (surplus of each treatment deduced from that of control) was shown to peak at US\$ $723.33 \cdot \mathrm{ha}^{-1}$ for the $\mathrm{N}$ rate of $100 \mathrm{~kg} \cdot \mathrm{ha}^{-1}$.

\section{CONCLUSION}

The fertilizer rate of $130 \mathrm{~kg} \mathrm{~N} \cdot \mathrm{ha}^{-1}$ required to obtain the highest stalk yield for green sugarcane is greater than the previously recommended dosage for the crop when it was burned before harvesting. However, considering the costs involved in the process and the economic benefits, the ideal rate would be $100 \mathrm{~kg} \mathrm{~N} \cdot \mathrm{ha}^{-1}$.

The NUE is between 40 and $50 \%$ when ammonium sulfate is used as $\mathrm{N}$ source, which is considered high and above the amount commonly obtained from fertilization with urea.

The sugar content is only slightly affected by increasing $\mathrm{N}$ fertilization rates compared to the large increase in sugar yield.

\section{REFERENCES}

Ambrosano, E. J., Trivelin, P. C. O., Cantarella, H., Ambrosano, G. M. B., Schammass, E. A., Guirado, N., Rossi, F., Mendes, P. C. D. and Muraoka, T. (2005). Utilization of nitrogen from green manure and mineral fertilizer by sugarcane. Scientia Agricola, 62, 534542. http://dx.doi.org/10.1590/S0103-90162005000600004.

Arnold, S. L. and Schepers, J. S. (2004). A simple roller-mill grinding procedure for plant and soil samples. Communications in Soil Science and Plant Analysis, 35, 537-545. http://dx.doi. org/10.1081/CSS-120029730.

Balasubramanian, V., Alves, B., Aulakh, M., Bekunda, M., Cai, Z., Drinkwater, L., Mugendi, D., Kessel, C. and van Oenema O. (2004). Crop, environmental, and management factors affecting nitrogen use efficiency. In A. R. Mosier, J. K. Syers and J. Freney (Eds.), Agriculture and the nitrogen cycle (p. 19-33). Washington: Scientific Committee on Problems of the Environment.

Baligar, V. C., Fageria, N. K. and He, Z. L. (2001). Nutrient use efficiency in plants. Communications in Soil Science and Plant Analysis, 32, 921-950. http://dx.doi.org/10.1081/CSS-100104098.

Boddey, R. M., Xavier, D., Alves, B. J. R. and Urquiaga, S. (2003). Brazilian agriculture: the transition to sustainability. Journal of Crop Production, 9, 593-621. http://dx.doi.org/10.1300/J144v09n01_10.

Brackin, R., Näsholm, T., Robinson, N., Guillou, S., Vinall, K., Lakshmanan, P., Schmidt, S. and Inselsbacher, E. (2015). Nitrogen fluxes at the root-soil interface show a mismatch of nitrogen fertilizer supply and sugarcane root uptake capacity. Scientific Reports, 5, Article ID 15727. http://dx.doi.org/10.1038/ srep15727.
Bremner, J. M. and Mulvaney, C. S. (1982). Nitrogen total. In A. L. Page (Ed.), Methods of soil analysis: part 2 (p. 595-624). Madison: American Society of Agronomy.

Cantarella, H., Trivelin, P. C. O., Contin, T. L. M., Dias, F. L. F., Rossetto, R., Marcelino, R., Coimbra, R. B. and Quaggio, J. A. (2008). Ammonia volatilisation from urease inhibitor-treated urea applied to sugarcane trash blankets. Scientia Agricola, 65, 397-401. http://dx.doi.org/10.1590/S0103-90162008000400011.

Cantarella, H., Trivelin, P. C. O. and Vitti, A. C. (2007). Nitrogen and sulphur in sugarcane. In T. Yamada, S. R. S. Abdalla and G. C. Vitti (Eds.), Nitrogen and sulphur in Brazilian agriculture (p. 355-412). Piracicaba: International Plant Nutrition Institute.

Castro, S. G. Q., Franco, H. C. J. and Mutton, M. A. (2014). Harvest management and cultural practices in sugarcane. Revista Brasileira de Ciência do Solo, 38, 299-306. http://dx.doi. org/10.1590/S0100-06832014000100030.

Conselho dos Produtores de Cana-de-Açúcar, Açúcar e Álcool do Estado de São Paulo (2006). Manual de instruções. 5. ed. Piracicaba: Consecana; [accessed 2016 May 11]. http://www. orplana.com.br/manual_2006.pdf

Costa, M. C. G., Vitti, G. C. and Cantarella, H. (2003). N-NH losses $_{3}$ from nitrogen sources applied over unburned sugarcane straw. Revista Brasileira de Ciência do Solo, 27, 631-637. http://dx.doi. org/10.1590/S0100-06832003000400007.

Dourado Neto, D., Powlson, D., Abu Bakar, R., Bacchi, O. O. S., Basanta, M. V., Thi Cong, P., Keerthisinghe, G., Ismaili, M., Rahman, 
S. M., Reichardt, K., Safwat, M. S. A., Sangakkara, R., Timm, L. C., Wang, J. Y., Zagal, E. and van Kessel, C. (2010). Multiseason recoveries of organic and inorganic nitrogen-15 in tropical cropping systems. Soil Science Society of America Journal, 74, 139 -152.

Fernandes, A. C. (2011). Cálculos na agroindústria da cana-deaçúcar. 3. ed. Piracicaba: STAB.

Fortes, C., Trivelin, P. C. O. and Vitti, A. C. (2012). Long-term decomposition of sugarcane harvest residues in Sao Paulo state, Brazil. Biomass and Bioenergy, 42, 189-198. http://dx.doi. org/10.1016/j.biombioe.2012.03.011.

Fortes, C., Trivelin, P. C. O., Vitti, A. C., Otto, R., Franco, H. C. J. and Faroni, C. E. (2013). Stalk and sucrose yield in response to nitrogen fertilization of sugarcane under reduced tillage. Pesquisa Agropecuária Brasileira, 48, 88-96. http://dx.doi. org/10.1590/S0100-204X2013000100012.

Franco, H. C. J., Otto, R., Faroni, C. E., Vitti, A. C., Oliveira, E. C. A. and Trivelin, P. C. O. (2011). Nitrogen in sugarcane derived from fertilizer in Brazilian field conditions. Field Crops Research, 121, 29-41. http://dx.doi.org/10.1016/j.fcr.2010.11.011.

Franco, H. C. J., Trivelin, P. C. O., Faroni, C. E., Vitti, A. C. and Otto, R. (2010). Stalk yield and technological attributes of planted cane as related to nitrogen fertilization. Scientia Agricola, 67, 579-590. http://dx.doi.org/10.1590/S0103-90162010000500012.

Gava, G. J. C., Trivelin, P. C. O., Vitti, A. C. and Oliveira, M. W. (2005). Urea and sugarcane straw nitrogen balance in a soil-sugarcane crop system. Pesquisa Agropecuária Brasileira, 40, 689-695. http://dx.doi.org/10.1590/S0100-204X2005000700010.

Instituto Brasileiro de Geografia e Estatística (2016). Levantamento sistemático da produção agrícola. Sistema IBGE de Recuperação Automática - SIDRA; [accessed 2016 Apr 25]. www.ibge. gov.br

Instituto Nacional de Pesquisas Espaciais (2014). Monitoramento da cana-de-açúcar via imagens de satélite; [accessed 2014 Nov 8]. http://www.dsr.inpe.br/laf/canasat/

Korndorfer, G. H. and Martins, M. (1992). Importância da adubação na qualidade da cana de açúcar. STAB, 10, 26-31.

Martinelli, L. A. and Filoso, S. (2008). Expansion of sugarcane ethanol production in Brazil: environmental and social challenges. Ecological Applications, 18, 885-898. http:// dx.doi.org/10.1890/07-1813.1.
Mead, R. and Pike, D. J. (1975) A review of response surface methodology from a biometric viewpoint. Biometrics, 31 , 803-851.

Meier, E. A., Thorburn, P. J., Wegener, M. K. and Basford, K. E. (2006). The availability of nitrogen from sugarcane trash on contrasting soils in the wet tropics of North Queensland. Nutrient Cycling in Agroecosystems, 75, 101-114. http://dx.doi. org/10.1007/s10705-006-9015-0.

Oliveira, A. P. P., Thorburn, P. J., Biggs, J. S., Lima, E., Anjos, L. H. C., Pereira, M. G. and Zanotti, N. E. (2015). The response of sugarcane to trash retention and nitrogen in the Brazilian coastal tablelands: a simulation study. Experimental Agriculture, 1, 1-18. http://dx.doi.org/10.1017/S0014479714000568.

Otto, R., Castro, S. A. Q., Mariano, E., Castro, S. G. Q., Franco, H. C. J. and Trivelin, P. C. O. (2016). Nitrogen use efficiency for sugarcane-biofuel production: what is next? Bioenergy Research, 9, 1272-1289. http://dx.doi.org/10.1007/s12155-016-9763-x.

Prado, R. M. and Pancelli, M. A. (2008). Resposta de soqueiras de cana-de-açúcar à aplicação de nitrogênio em sistema de colheita sem queima. Bragantia, 67, 951-959. http://dx.doi. org/10.1590/S0006-87052008000400018.

Ramos, M. G., Villatoro, M. A. A., Urquiaga, S., Alves, B. J. R. and Boddey, R. M. (2001). Quantification of the contribution of biological nitrogen fixation to tropical green manure crops and the residual benefit to a subsequent maize crop using $15 \mathrm{~N}$-isotope techniques. Journal of Biotechnology, 91, 105-115. http://dx.doi.org/10.1016/S0168-1656(01)00335-2.

Reis Junior, R. A. (2001). Probabilidade de resposta da cana-de-açúcar à adubação potássica em razão da relação $\mathrm{K}+\left(\mathrm{Ca}^{2+}+\mathrm{Mg}^{2+}\right)^{-0,5}$ do solo. Pesquisa Agropecuária Brasileira, 36 , 1175-1183. http://dx.doi.org/10.1590/S0100-204X2001000900011.

Robertson, F. A. and Thorburn, P. J. (2007a). Decomposition of sugarcane harvest residue in different climatic zones. Australian Journal of Soil Research, 45, 1-11. http://dx.doi. org/10.1071/SR06079.

Robertson, F. A. and Thorburn, P. J. (2007b). Management of sugarcane harvest residues: consequences for soil $\mathrm{C}$ and $\mathrm{N}$. Australian Journal of Soil Research, 45, 13-23. http://dx.doi. org/10.1071/SR06080.

Rosa, H. J. A., Amaral, L. R., Molin, J. P. and Cantarella, H. (2015). Sugarcane response to nitrogen rates, measured by a canopy reflectance sensor. Pesquisa Agropecuária 
Brasileira, 50, 840-848. http://dx.doi.org/10.1590/ s0100-204X2015000900013.

Silva, F. C. (1999). Manual de análises químicas de solos, plantas e fertilizantes. Brasília: Embrapa.

Soil Survey Staff (2014). Keys to soil taxonomy. 12. ed. Washington: USDA, Natural Resources Conservation Service.

Trivelin, P. C. O., Victoria, R. L. and Rodrigues, J. C. (1996). Utilização por soqueira de cana-de-açúcar de início de safra do nitrogênio da aquamônia-15N e uréia-15N aplicado ao solo em complemento à vinhaça. Pesquisa Agropecuária Brasileira, 31, 89-99.

Universidade Federal de Viçosa (2007). SAEG: sistema para análises estatísticas. Versão 9.1. Viçosa: Fundação Arthur Bernardes, UFV.

Universidade Federal Rural do Rio de Janeiro (2013). Manual de calagem e adubação do Estado do Rio de Janeiro. Seropédica: UFRRJ.

Urquiaga, S., Xavier, R. P., Morais, R. F., Batista, R. B., Schultz, N., Leite, J. M., Sá, J. M. E., Barbosa, K. P., Resende, A. S. D., Alves, B. J. R. and Boddey, R. M. (2012). Evidence from field nitrogen balance and $15 \mathrm{~N}$ natural abundance data for the contribution of biological N2 fixation to Brazilian sugarcane varieties. Plant and Soil, 356, 521. http://dx.doi.org/10.1007/ s11104-011-1016-3.

Vieira-Megda, M. X., Mariano, E., Leite, J. M., Franco, H. C. J., Vitti, A. C., Megda, M. M., Khan, S. A., Mulvaney, R. L. and Trivelin, P. C. O. (2015). Contribution of fertilizer nitrogen to the total nitrogen extracted by sugarcane under Brazilian field conditions. Nutrient Cycling in Agroecosystems, 101, 241-257. http://dx.doi.org/10.1007/s10705-015-9676-7.

Vitti, A. C., Trivelin, P. C. O., Gava, G. J. C., Franco, H. C. J., Bologna, I. R. and Faroni, C. E. (2007). Produtividade da canade-açúcar relacionada à localização de adubos nitrogenados aplicados sobre os resíduos culturais em canavial sem queima. Revista Brasileira de Ciência do Solo, 3, 491-498. http://dx.doi. org/10.1590/S0100-06832007000300009.

Wiedenfeld, R. P. (1995). Effects of irrigation and N fertilizer application on sugarcane yield and quality. Field Crops Research, 43, 101-108. http://dx.doi.org/10.1016/0378-4290(95)00043-P. Yamada, S., Osaki, M., Shinano, T., Yamada, M., Itob, M. and Permana, A. T. (2002). Effect of potassium nutrition on current photosynthesized carbon distribution to carbon and nitrogen compounds among rice, soybean, and sunflower. Journal of Plant Nutrition, 25, 1957-1973. http://dx.doi.org/10.1081/ PLN-120013287. 